\title{
Using Emojis In Whatsapp Group Messaging Throughout Communication Process
}

\author{
Bayındır, B. ${ }^{1}$ \\ ${ }^{1}$ Berkan BAYINDIR, İstanbul Aydın University, (Turkey) \\ e-mail: berkanbayindir@stu.aydin.edu.tr
}

\begin{abstract}
In this study if emojis in the application called WhatsApp are used or not in the process of communication by people who are members of $X$ generation is going to be searched out. It is assumed that people who were born in 1965-1979 and regarded as X generation also use new means of communication and the features of the new technologies in their daily life. The sample group of this search has been chosen from a number of foreign language teachers who work in a public high school in Turkey and use the application in their daily lives. By participating to their messaging group, the messages are going to be observed and their content analyze is going to be done. Also data about the usage of emojis in that messaging group during the communication process is going to be gathered and then interpreted. Later a questionnaire is going to be asked to the members of the messaging group to cross check their thoughts about the application and also about the emojis.
\end{abstract}

Keywords: Emoji, Group Messaging, Communication Process, Social Network, WhatsApp

\section{Introduction}

As a result of the necessity that human beings need to live in a society, the importance of communication cannot be ignored in our lives. Oskay mentions that the important improvements from the time when Homéros lived to the time when Industry Revolution took place happened in transportation and communication field which was depended on mostly transportation are the leading innovations (2014: 29). Since the second half of $19^{\text {th }}$ century the studies done in the communication field helped communication to become a scientific field. Although the rapid developments in technology are difficult to follow, the convenience they provide in our daily lives and especially the improvements which help us to communicate without the restrictions of time and space made these improvements indispensable for us in daily life.

With the digitalization of media, touch screen devices became part of daily life and this changed the notion of communicating into a different level. The technological devices which we have seen in $20^{\text {th }}$ century are now being used daily in the $21^{\text {st }}$ century. In fact, every new device is a new concept that serves to culture industry as well. People are depended on culture industries for images, signs and vocabulary knowledge that they use for interpretation of their social environments and to respond them (Golding \& Murdock, 1997: 49). As people can carry these communication devices in their pockets or bags and with the advance of internet these media devices are not only used for communication but also they are used for different purposes at the same. Mobile phones are indispensable for us now and that is why more applications are being developed for different needs.

With the invention of each new communication device, the effects of them on individuals and society become the subject of scientific studies (Oskay, 2002: 44). The main aim of this study is to find out whether the application is used effectively by people who are members of $X$ generation, in addition how frequently and for which occasions the emojis of WhatsApp application are used for by a number of teachers. It is assumed that new technologies are not only used by people who were born in the digital era but also they are used by the ones who were born before the digital era.

On $15^{\text {th }}$ July 2016 , some of the active duty officers of Turkish Army used this application in their communication process during the coup attempt and that was just another example of using the application for different purposes in the communication process and it also shows that the application 
is used by lots of people for different needs during the communication process. In this study, it is going to be searched out if emojis are preferred in the communication process and for which emotions or feelings they are used for by people who were born in the years 1965-1979 and regarded as $X$ generation.

\section{Basic Communication Process}

For many reasons people choose to live in a society. We need to communicate for sure to continue our daily lives and to accommodate ourselves to the society that we are living in. So first of all the definition of communication which has an important place in the life of an individual must be given.

The word communication was derived from the Latin word communis (Bektaş, 2013: 98). There are nearly 200 definitions about communication (Mutlu, 1995: 168). When we look up the dictionary of Turkish Language Institution, we find two definitions. The first one is explained as; transferring the emotions, thoughts and information to other people with any channel that can be imaginable (Parlatır et. al., 1998: 1067). In the second definition the technical side of communication is explained. The process which is done by using devices like telephone, telegraph, television and radio (Parlatır et. al., 1998: 1067-1068). Yengin points out that we need communication in the first place to continue our lives (2014: 1). Oskay says; communication is the product of human existence and this notion belongs to humans and it changes as far as the life style of humans change (2015: 15).

Although there is a compromise on the words which correspond to communication, there is still no exact compromise on conceptualizing its definition and process (Güngör, 2016: 54). Up to now a lot of scientists and thinkers have theorized and modeled the communication process. There are relatively many models about this process and this shows us that the changes in the process are still going on. Due to the rapid improvements in technology more and more new channels are being invented and new ways of communication are being used.

\section{Social Communication Network}

Before thinking on social communication network first of all the communication network is going to be explained in this part of the study. The cooperation or contact between communication devices is called as communication network (Parlatır et. al., 1998: 1068). If an individual uses one of these communication devices and interacts with other people, it means that he or she is using social communication network. Communication networks are very common in communication because in societies so many people are connected to one or more of them (Mutlu, 1995: 169). Because of the changes in technology, in today's world, communication itself is also changing and is used in different environments and in different circumstances.

The improvements and changes in computer and mobile technologies also affect the communication process. It is now considered as the restrictions of time and space do not exist anymore. Due to the rapid improvements in the internet technology and the connection of devices via internet networks, the communication process has become faster and easier. Stevenson mentions that the radical effects of new communication ways on space, time and individual's perception form the main subjects of Marshall McLuhan's studies (2015: 196). McLuhan's Global Village term becomes more visible day by day with the improvements in internet and mobile technologies.

In the past, in order to socialize, humans need to get together with one or more people in a particular place and then communicate with each other, but today if an individual has a computer or a mobile device that has an internet access, he/she can interact with others without the limitations of time and space. The new media technologies have changed the ways of our participation in social life without the necessity of any special knowledge (Stevenson, 2015: 209). Communication and social relations also digitalized with the media itself. Users can monitor the content and choose them and at the same time communication has changed from one way into interactive communication (Yengin, 2014: 117). Throughout interactive communication process people express themselves in digital spaces which are called as social networks and they become digitally socialized while they are sharing posts.

\section{WhatsApp as a Social Network}


The amazing improvements in mobile phone technologies made them more than just a device which are used only for voice calls. At the end of 90's the mobile phones, either produced in Turkey or imported from other countries, were being sold in the market of Turkey. Though they were called as pocket phones at the same time, in fact they were too thick to carry in a pocket of a trouser. Because they were too thick, some accessories like belt cases, especially for men, were indispensable.

When we compare old mobile phones with today's phones, being thick was not the only negative side of them. If a short comparison is done; in the past mobile phones had small and monochrome screens, they could only be used for voice calls or texting, their menu could be reached with a keypad and also their capacity were limited. But having the ability of communicating without wires made them more popular day by day. Today, mobile phones are lighter and slimmer; they have touch screens which are colorful and bigger, their memory capacity are more extended, they can be used in social networks thanks to their internet connection features and they are like small computers that can be easily carried in pockets.

Mobile phones are also called as smart phones nowadays. In fact, by naming them as smart means, they turned into technological devices which are not only used only for voice calls or texting but also they have many features like taking photographs, recording videos, storing music or documents etc. "The new technologies which are digitalized enabled the communication technology to be used for different purposes" (Özel \& Sert, 2015: 7). With the help of applications which are developed for mobile phones, they can show you the weather forecast, keep track of one's fitness or health, and enable the user to join in social media, follow the news and so on. As Jenkins points out that these features are also examples of 'Media Convergence' at the same time (2016. 17-37). Many people feel themselves restless and uncomfortable if they forget to take their phones with them. Dijk says; "particularly the youth in rich countries cannot even imagine a world without mobile services, internet and Facebook or other social media sites" (2016: 12).

Many applications are made for mobile phones which became inseparable from the communication process in the digital era. Some of these applications are sold in virtual shops like 'playstore' or 'apple store' and some of them can be downloaded for free. WhatsApp is one of these applications that can be downloaded for free. It is also one of the most preferred applications for instant messaging. "WhatsApp was established by ex Yahoo employees Brian Acton and Jan Koum in California, U.S.A" (Güçdemir, 2015: 50). With the application a user can send text and voice messages, share pictures, videos and files, also can add signs called emojis to the content. The emojis were predated by text-based symbols 'emoticons' which are used to express emotions. The word is formed as combo word from emotion and icon (Harper, 2010).

\section{Methodology}

Emerging technologies also change the ways of communication. In historical process, with the new technological inventions both social and inter personal relations are reshaped (Güçdemir, 2017: 4). Today people can communicate without any limitation of time and space; of course some countries still do not have the same opportunities though. The main hypothesis of this study is that new communication channels are used by people of $X$ generation. In context of this hypothesis it is also assumed that emojis are also used to express emotions and feeling during communication process. The study is limited with one month time period between 08.04.2017 and 09.05.2017. A questionnaire is given to the messaging group members on 09.05.2017 and that is why no more data is taken into consideration after that day in order not to affect the findings. Because it is thought that after the members had learnt that their message contents have been observed they may change their attitudes and affect the findings.

The author is one of the members of the messaging group and this lets him observe the messages and collect the necessary data. And this is the main reason of choosing the messaging group as a sample for the study. With the author there are nine participants in the group. Six of them are English teachers and three of them are German teachers. The teachers are coded with initial letters of their surnames and names in the analysis section of the study.

The messages and emojis in the messaging group are going to be examined with content analysis method. Because of its appropriateness to the study the content analysis method is preferred. With content analysis method one can quantize and identify the features of a particular text, book or document (Karasar, 1999: 184). In practice content analysis can be done in two ways depending on 
the purpose. These are field analysis and decoding the meaning of the message (Aziz, 2014: 135). And with the questionnaire given to the participants on 09.95.2017, the thoughts of the participants about the application and emojis are going to bedisclosed.

\section{Findings}

The messaging group was formed on 06.01 .2015 by K.S and nine foreign language teachers involved in the group. The aim of forming the group is mainly to share information about school subjects when the teachers are not together. When the demographic and sociological state questions of the questionnaire are examined, it is seen that the members of the group are between 35 to 59 years old so they can be considered as $\mathrm{X}$ generation. Seven members of the group are women and two of them are men. All of them have at least one child. All the members graduated from a university and the faculties which they were graduated from are all related with their profession. They have 1529 years of professional experience in teaching.

First of all the number of the shared posts and by whom they were shared is going to be determined and shown in the table. The participants are going to be coded with the initial letters of their surnames and names then sequenced alphabetically in the tables formed in the study. Examining the shared posts is going to help to find out if the messaging group is actively used or not.

Table 1: Number of shared posts in the application

\begin{tabular}{|c|c|c|}
\hline Item No & Participants & Number of Messages \\
\hline 1 & A.G & 30 \\
\hline 2 & A.D & 12 \\
\hline 3 & A.N & 14 \\
\hline 4 & B.B & 28 \\
\hline 5 & Ç.S & 26 \\
\hline 6 & K.S & 26 \\
\hline 7 & K.M & 78 \\
\hline 8 & T.I & - \\
\hline 9 & T.M & 18 \\
\hline
\end{tabular}

When table 1 is examined, it is seen that 232 messages shared in total. K.M shared the most posts; 78 posts in one month period. But on the other hand T.I didn't share any posts. Other participants shared $12-30$ posts. It is seen that except T.I every other member uses the messaging application actively in the communication process.

When emoji usage is examined during the one month period, it is seen that 151 emojis were used in the messaging group. In 81 of 232 shared posts just emojis were used to express feelings or thoughts. Other 70 emojis were used with texts in the shared posts. The study is going to continue with the table about emoji numbers and the participants who used them.

Table 2: The number of emojis used by the participants

\begin{tabular}{|c|c|c|}
\hline $\begin{array}{c}\text { Item } \\
\text { No }\end{array}$ & Participants & $\begin{array}{c}\text { Number } \\
\text { of } \\
\text { Emojis }\end{array}$ \\
\hline 1 & A.G & 34 \\
\hline 2 & A.D & - \\
\hline 3 & A.N & 5 \\
\hline 4 & B.B & 21 \\
\hline 5 & C.S & 1 \\
\hline
\end{tabular}




\begin{tabular}{|c|c|c|}
\hline 6 & K.S & 16 \\
\hline 7 & K.M & 63 \\
\hline 8 & T.I & - \\
\hline 9 & T.M & 11 \\
\hline
\end{tabular}

When table 2 is examined, it is understood that seven members used emojis during their communication process. Like in shared posts again K.M used the most emojis in number in one month time period. In the previous table 1 , there is only one participant who did not shared any posts, in addition in table 2 there is another member who did not used any emojis. Seven group members used emojis at least once and up to 63 times. Seven of nine members used emojis to express their feelings or thoughts and this shows that these icons are used frequently in the communication by people who are regarded as $\mathrm{X}$ generation.

In the following table which emojis are used and how often they are used is going to be searched out and then it will be seen which emoji is mostly preferred by the members of messaging group. In the table the emojis are going to be sequenced starting with the first emoji used in the communication process and followed by the others and then their frequency is going to be determined.

Table 3: Examining the emojis used in the messaging group

\begin{tabular}{|c|c|c|}
\hline $\begin{array}{l}\text { Item } \\
\text { No }\end{array}$ & Emoji & $\begin{array}{l}\text { Number of } \\
\text { Frequency }\end{array}$ \\
\hline 1 & $(E)$ & 2 \\
\hline 2 & $\Leftrightarrow$ & 58 \\
\hline 3 & $\xi$ & 12 \\
\hline 4 & $\odot$ & 4 \\
\hline 5 & {$[s]$} & 1 \\
\hline 6 & $g N$ & 1 \\
\hline 7 & {$[100$} & 1 \\
\hline 8 & 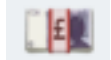 & 1 \\
\hline 9 & \$ & 1 \\
\hline 10 & & 1 \\
\hline 11 & & 1 \\
\hline 12 & 次 & 1 \\
\hline 13 & $\ddot{\theta}$ & 24 \\
\hline 14 & $\hat{\ominus}$ & 4 \\
\hline 15 & $\theta$ & 4 \\
\hline
\end{tabular}

\begin{tabular}{|l|l|l|}
\hline 16 & $\ddots$ & 4 \\
\hline 17 & $\ddots$ & 1 \\
\hline 18 & $\ddots$ & 5 \\
\hline 19 & $\ddots$ & 6 \\
\hline 20 & $\ddots$ & 1 \\
\hline 21 & $\ddots$ & 1 \\
\hline 22 & $\ddots$ & 7 \\
\hline 23 & $\ddots$ & 1 \\
\hline 24 & $\ddots$ & 1 \\
\hline 25 & $\ddots$ & 1 \\
\hline 26 & $\ddots$ & 1 \\
\hline 27 & $\ddots$ & 1 \\
\hline 28 & $\ddots 2$ & 1 \\
\hline 29 & $\ddots$ & 1 \\
\hline 30 & $\ddots$ & 1 \\
\hline
\end{tabular}


When table 3 is examined, it is seen that 30 different emojis were used in the communication process. In one month time period, the emoji which is in the second place in the table is the most preferred emoji with 58 times repetitions. The icon represents 'face with tears of joy' which was also named the word of the year in 2015 (Liberatore, 2017).

The second most preferred emoticon is the one which is shown in the $13^{\text {th }}$ place in table 3 and that is the emoticon which symbolizes 'grinning face', was used 24 times in one month period. It is seen that, in the messaging group when participants want to express their feelings about the content, especially when the content is funny, they prefer using emojis. The following section is going to be related with the participants' thoughts about the application and the emojis.

Table 4: Analyzing the responses to the questionnaire related with the thoughts about the application and emojis;

\begin{tabular}{|c|c|c|c|c|c|}
\hline \multicolumn{6}{|l|}{ PART (2) PURPOSES OF USING WHATSAPP } \\
\hline $\begin{array}{l}\text { Put a }(X) \text { sign next to the sentences which } \\
\text { are appropriate to you. }\end{array}$ & 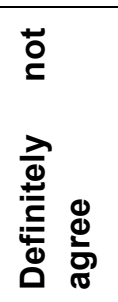 & 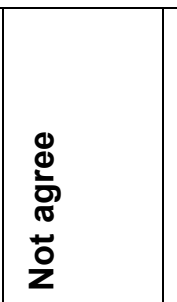 & 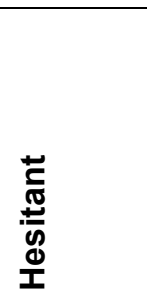 & ఖ & 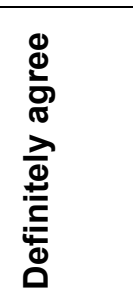 \\
\hline 1. I use the app to share news & & & $\begin{array}{c}1 \\
\text { person }\end{array}$ & $\begin{array}{c}3 \\
\text { people }\end{array}$ & $\begin{array}{c}4 \\
\text { people }\end{array}$ \\
\hline $\begin{array}{l}\text { 2. I share funny or interesting things } \\
\text { with the app }\end{array}$ & & & $\begin{array}{c}2 \\
\text { people }\end{array}$ & $\begin{array}{c}3 \\
\text { people }\end{array}$ & $\begin{array}{c}3 \\
\text { people }\end{array}$ \\
\hline 3. I use the app to share photos & & $\begin{array}{c}1 \\
\text { person }\end{array}$ & & $\begin{array}{c}3 \\
\text { people }\end{array}$ & $\begin{array}{c}4 \\
\text { people }\end{array}$ \\
\hline $\begin{array}{l}\text { 4. I use the app to organize an } \\
\text { event/occasion }\end{array}$ & & & $\begin{array}{c}4 \\
\text { people }\end{array}$ & $\begin{array}{c}2 \\
\text { people }\end{array}$ & $\begin{array}{c}2 \\
\text { people }\end{array}$ \\
\hline $\begin{array}{l}\text { 5. Other } \\
\text { (If there is other things you use the } \\
\text { app for please write them) }\end{array}$ & \multicolumn{5}{|c|}{-} \\
\hline $\begin{array}{l}\text { 6. How long have you been using the } \\
\text { app? }\end{array}$ & \multicolumn{2}{|c|}{$\begin{array}{l}\text { ( - ) } 0-1 \text { year } \\
\text { ( } 2 \text { people) } 2-3 \text { years } \\
\text { ( } 1 \text { people) } 4-5 \text { years }\end{array}$} & \multicolumn{3}{|c|}{$\begin{array}{l}\text { ( } 2 \text { people) } 1-2 \text { years } \\
(2 \text { people }) 3-4 \text { years } \\
(1 \text { people }) 5-6 \text { years }\end{array}$} \\
\hline 7. Do you find the app useful? & \multicolumn{3}{|c|}{ (8 people) Yes (- ) No } & \multicolumn{2}{|c|}{ ( - ) Partly } \\
\hline 8. Do you use any other similar apps? & \multicolumn{5}{|c|}{ ( 4 people) Yes } \\
\hline $\begin{array}{l}\text { 9. If your answer is 'yes' to question } 8 \\
\text { please tick the app/apps that you are } \\
\text { using. }\end{array}$ & \multicolumn{3}{|c|}{$\begin{array}{l}\text { ( 1person) Viber } \\
\text { ( } 4 \text { people) Messenger } \\
\text { ( - ) iMessenger }\end{array}$} & \multicolumn{2}{|c|}{$\begin{array}{l}\text { - ) Tango } \\
\text { - ) Line } \\
\text { ( } 3 \text { people) Other }\end{array}$} \\
\hline 10. Do you use the emojis in the app? & \multicolumn{5}{|c|}{ ( 8 people) Yes $\quad(-)$ No } \\
\hline 11. Do you like receiving emojis? & \multicolumn{5}{|c|}{ (7 people) Yes ( - ) No $\quad$ (1 person ) Hesitant } \\
\hline
\end{tabular}




\begin{tabular}{|c|c|}
\hline $\begin{array}{l}\text { 12. How will you feel if the emojis are } \\
\text { removed from the app? }\end{array}$ & $\begin{array}{l}\text { ( } 2 \text { people) Sad } \quad \text { ( } 5 \text { people) Little bit sad } \\
\text { ( } 1 \text { person ) Doesn't matter } \\
\begin{array}{ll}\text { ( - ) Happy } & \text { ( - ) Very happy }\end{array}\end{array}$ \\
\hline $\begin{array}{l}\text { 13. Can you express your feelings } \\
\text { enough with the emojis? }\end{array}$ & ( - ) Yes ( 2 people) No ( 6 people) Hesitant \\
\hline
\end{tabular}

Table 4 is formed with the second part of the questionnaire which was applied to the members of the messaging group on 09.05.2017. In this section, in order to determine the participants' thoughts about the application and the emojis, the numbers of participants are written next to the options. When an overview examination is done, it is seen that the members of the messaging group use the application to share news, funny or interesting occasions and also to share photographs besides it is understood that they hesitate to plan an event or an occasion with the application. All the members of the messaging group are using the application at least more than a year and they also think that it is a useful application. In addition half of the participants mentioned that they also use other similar applications.

In the part which is related with emojis all the participants expressed that they use emojis in the process of communication and also seven of them pointed out that they like receiving emoticons too. Five of the participants expressed that they would be a little bit sad, two of them mentioned that they would be sad and only one of them chose the option that it doesn't matter if the emojis were removed from the application. Two of the participants mentioned that they express their feeling and thoughts well enough with the emojis whereas six of them mentioned that they are not very sure about it.

\section{Conclusion}

The communication process is also changing with the emerging technology. Especially in the last 20 years with the development of internet and mobile technologies, the limitation of time and space in the communication process is nearly out of date now. Having a mobile device which has an internet connection, people can communicate and interact with each other whenever they like and wherever they go. Generally technological determinists think that these opportunities help the world turn into a 'global village' and comfort our lives. On the other hand the ones who approach critically to these improvements think that individuals are depended on these technologies more than they need and they behave like volunteer labors while they are producing the content. Last but not least people are living in a society where constant surveillance is part of their life thanks to these technologies. There is no doubt about some of these and other similar comments are true to some extent. But while people are living their daily lives they also try to adapt their selves to these new technologies. Many of them may have their own reasons, particularly the ones who are called digital-born. These teenagers who were born in the digital era cannot even imagine themselves without new media and new technologies. Meanwhile the ones who try to adapt themselves to the requirements of the digital era usually witness these processes because technological developments also cause change in their habits of living styles.

The usage of an application named WhatsApp and whether it is used effectively or not by some people who faced with the application lately in their lives and who are also members of $X$ generation was the main starting point of this study. In this context, the core hypothesis of the study which is new ways of communication are also used by members of $X$ generation is searched out by content analysis method and a questionnaire. To collect the necessary data the shared messages are analyzed and a research is conducted about the icons called emojis. At the end of one month period a questionnaire was given to the members of the messaging group to find out more detailed information about how emojis and the application is used by the participants.

In this study which is limited with one month time period, it is seen that eight of the participants, who are also members of $X$ generation, use the messaging application actively, only one of them did not share any posts during the study. So it can be said that people who are members of $X$ generation adapt themselves to the new ways of communication and they use these technologies in their daily lives. When the questionnaire is examined it is seen that the participants prefer to use emojis and they also like to receive them too. They also usually prefer to use emojis to express their 
feelings and thoughts. The most preferred emojis are the ones that symbolize laughing when a funny content is shared by one of the members. Especially the one that is named as 'face with tears of joy' was the most preferred emoji in this study. "In the study conducted by University of Michigan; after analyzing millions messages across the globe, researchers discovered that the smiling face with tears streaming from its eyes accounts for 15.4 percent of the emoji usage" (Liberatore, 2017). Also this study discovers similar findings about emoji usage.

The overall result of this study can be summarized as people who are members of $X$ generation adapt their selves to the new ways of communication and they use these technologies in their daily lives. Chayko points out "Just as using new technological devices or platforms is usually confusing or clunky at first but becomes easier with time, digital technology tends to be integrated and folded into the everyday life of people in tech-rich communities and societies" (2017: 66). Also the icons which are called as emojis are usually preferred in the communication process while sending messages with the application called WhatsApp. At the same time the emojis which represent laughing are the most preferred ones while expressing feelings and thoughts. These findings show us that when something is practical and available it is preferred by people from different age groups. As it is mentioned at the beginning of the study technologies and applications are being improved and developed day by day. In this context change is something which people often experience in their daily lives. As a proof of this statement a different kind of emoji has been released by Apple Company recently. These new forms of emojis are called as 'animojis'. Mainly, these animated emojis can mirror individual's expressions and even move its mouth when the individual speaks (Molina, 2017). It is seen that ways of communication is changing with the developing technology so we had better adapt ourselves to it rather than resisting it.

\section{References}

[1] Aziz, A. (2014). Sosyal Bilimlerde Araştırma Yöntemleri ve Teknikleri. 9. Baskı. Ankara: Nobel Akademik Yayıncılık Eğitim Danışmanlık Tic. Ltd. Şti.

[2] Bektaş, A. (2013). Kamuoyu, İletişim ve Demokrasi. İstanbul: Bağlam Yayınları.

[3] Chayko, M. (2017). Superconnected: The Internet, Digital Media, \& Techno-Social Life. London: Sage Publications.

[4] Güngör, N. (2016). İletişim Kuramlar ve Yaklaşımlar. Ankara: Siyasal Kitabevi.

[5] Güçdemir, Y. (2015). Sanal Ortamda İletişim, Bir Halkla ilişkiler Perspektifi. Üçüncü Basım, İstanbul: Derin Yayınları.

[6] Güçdemir, Y. (2017). Sosyal Medya: Halkla İlişkiler, Reklam ve Pazarlama. İstanbul: Derin Yayınları.

[7] Dijk, V., J. (2016). Ağ Toplumu. Çev., Özlem Sakin. İstanbul: Epsilon Yayıncılık.

[8] Golding, P. \& Murdock, G. (1997). Kültür, İletişim ve Ekonomi Politik. Süleyman İrvan (der.) içinde. Birinci Basım. Ankara: Bilim Sanat Yayınları/Ark Kitapları.

[9] Harper, D. (2010). Online Etymology Dictionary. Cited from http://www.dictionary.com/browse/emoticon (06.11.2017).

[10] Jenkins, H. (2016). Cesur Yeni Medya Teknolojiler ve Hayran Kültürü. Çev., Nihan Yeğengil. İstanbul: İletişim Yayınları.

[11] Karasar, N. (1999). Bilimsel Araştırma Yöntemi. Ankara: Nobel Yayın Dağıtım.

[12] Liberatore, S. (2017). Crying its way to the top of the chart: 'Face with tears of joy' revealed as world's most popular emoji. Cited from http://www.dailymail.co.uk/sciencetech/article4089052/Crying-way-chart-Face-tears-joy-revealed-world-s-popular-emoji.html (06.11.2017).

[13] Mutlu, E. (1995). İletişim Sözlüğü. 2. Basım. Ankara: Ark Yayınevi.

[14] Molina, B. (2017). Why 'animoji karaoke' is the best thing about iPhone X. USA Today. Cited from https://www.usatoday.com/story/tech/talkingtech/2017/11/06/animoji-karaokeiphone/835225001/ (07.11.2017).

[15] Oktay, M. (2002). Politikada Halkla Illişkiler. İstanbul: Der Yayınları.

[16] Oskay, Ü. (2014). Kitle İletişiminin Kültürel İşlevleri, XIX Yüzyıldan Günümüze Kuramsal Bir Yaklaşım. İstanbul: İnkılap Kitabevi.

[17] Oskay, Ü. (2015). İletişimin ABC'si. İstanbul: İnkılap Kitapevi.

[18] Özel, A. \& Sert, Y., N. (2015). Dijital Halkla İlişkiler Kavram ve Araçları. İstanbul: Derin Yayınları.

[19] Parlatır, İ., vd. (1988). Türk Dil Kurumu Türkçe Sözlük. Ankara: Türk Tarih Kurumu Basım Evi.

[20] Stevenson, N. (2015). Medya Kültürleri Sosyal Teori ve Kitle Illetişimi. Çev., Göze Orhon ve Barış Engin Aksoy. Ankara: Ütopya Yayınevi.

[21] Yengin, D. (2014). Yeni Medya ve Dokunmatik Toplum. İstanbul: Derin Yayınları. 